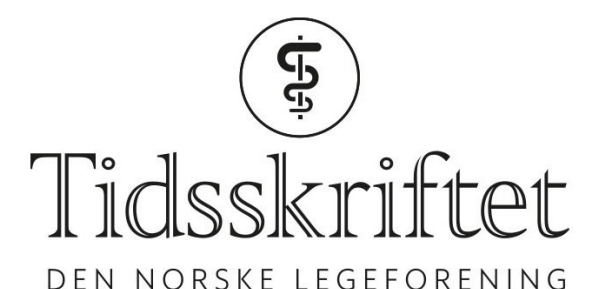

DEN NORSKE LEGEFORENING

\title{
Dr. Fo R. Dom møter dr. Lur N. Dreier
}

KOMMENTAR

\section{TORBEN WISBORG}

E-post: torben.wisborg@uit.no

Torben Wisborg er overlege og professor ved Universitetet i Tromsø.

Ingen oppgitte interessekonflikter.

Brean er i lederen «Dr. Dreiers metode» bekymret for det økende antall tvilsomme eller klart svindelbaserte invitasjoner til konferanser som ikke eksisterer (1). Problemet er helt reelt, og økende krav til vitenskapelig produksjon, meritering og telling av publikasjonspoeng gjør det meget betimelig å diskutere det.

Dessverre ser det ut til at dr. Lur N. Dreier møter dr. Fo R. Dom i døren. Brean mener at risikoen for å havne i fella - bevisst eller ubevisst - er størst for «de minst ressurssterke», nemlig "forskere fra utviklingsland, men også forskere fra vår del av verden, særlig fra mindre universiteter og høyskoler med små ressurser eller liten forskningsaktivitet». Utviklingsland er det som nå kalles lav- og mellominnkomstland.

Som forsker fra et lite sykehus og mindre universitet etterlyser jeg empirien bak frykten. De seneste norske skandaler har jo vært høyt meriterte, sentrale forskere i samarbeid med Jon Sudbø i 2006, og nyere hendelser er rapportert fra BI 2012 (2), i Uppsala mai 2017 (3) og Karolinska Institutets Paolo Macchiarini. Fra Danmark kan nevnes en kohort av kardiologer på universitetsklinikkene, som utviklet et kollektivt, meget kreativt syn på bruk av forskningsmidler (4). Men at forskere ved de mindre institusjoner skulle være i spesiell fare er dårlig underbygget. Hvor er dokumentasjonen? Var det dr. Fo R. Dom som kom forbi?

\section{LITTERATUR:}

1. Brean A. Dr. Dreiers metode. Tidsskr Nor Legeforen 2017; 137: 1663.

2. Heyerdahl S, Grønli H, Sættem JB. BI-rektor ville frikjenne forskningsjuks. NRK.

https://www.nrk.no/norge/_-rektor-ville-frikjenne-plagiat-1.8084075 (4.12.2017).

3. Rygg I. NTNU-forsker avslørte forskningsfusk ved Uppsala. Uniforum.

http://www.uniforum.uio.no/nyheter/2017/o5/ntnu-forsker-avslorte-forskningsfusk-ved-uppsala.html (4.12.2017).

4. DR. Op mod 15 hjertelæger risikerer straf for forskningsfusk.

https://www.dr.dk/nyheder/indland/op-mod-15-hjertelaeger-risikerer-straf-forskningsfusk (4.12.2017).

Publisert: 22. januar 2018. Tidsskr Nor Legeforen. DOI: 10.4045/tidsskr.18.0oo9

(C) Tidsskrift for Den norske legeforening 2020. Lastet ned fra tidsskriftet.no 